\title{
ARTYKUŁY
}

Klio. Czasopismo poświęcone dziejom Polski i powszechnym PL ISSN 1643-8191, t. 57 (1)/2021, s. 57-88

(c) $(1) \Theta$

KAROL ŁOPATECKI ${ }^{*}$

\section{The role of Russian army cartographers during the Great Northern War - the example of the Campaign of Grodno of $1706^{* *}$}

\begin{abstract}
This aim of this article is to analyse the role of cartography in operational activities during the Great Northern War. So far, only Swedish materials from that period have been studied, and this work involves two maps made for the needs of the Russian army by Engineer-General Joseph-Gaspar Lambert de Guerin (in Russian: Žozef Gaspar Lamber de Geren [Жозеф Гаспар Аамбер де Герен]). They were produced within the first three months of 1706 for the needs of the so-called Campaign of Grodno. Cartographic materials show that the Russian army comissioned engineers to conduct a preliminary terrain survey at the time. Initially, the officers devised marching routes from Grodno to Tykocin (only one such map has been preserved: Carte d'une partie de la Lithuanie et de la Pologne). At least four such routes were surveyed; three places were also found where the Neman
\end{abstract}

* Faculty of History and International Relations, University of Białystok, Plac Niezależnego Zrzeszenia Studentów 1, 15-420 Białystok, k.lopatecki@uwb.edu.pl, ORCID: 0000-0002-7921-9421.

** The article was written as part of the research project of the National Science Centre OPUS-16 (contract no. UMO-2018/31/B/HS3/00846) titled "The social and economic importance of military camps and garrisons in the Polish-Lithuanian state $\left(16^{\text {th }}-18^{\text {th }} \mathrm{c}\right.$.)" ["Społeczne i gospodarcze znaczenie obozów i garnizonów wojskowych w państwie polsko-litewskim (XVI-XVIII wiek)”]. 
river could be crossed, as well as fords and bridges that allowed the army to cross over the Biebrza river. Then, in the second phase, as the whole army had to flee from Swedish troops, all the routes were combined on one map: Environs de Grodno et Ticochin. This text presents the mistakes made by Lambert when producing this map. Despite its imperfections, the cartographic documentation contributed to the successful escape of the Russian forces from Grodno (22.03/2.04). After reaching Tykocin, Peter I's troops successfully crossed the Narew river (29.03/9.04) and then went toward Brest Litovsk (4/15.04). The estimated average daily marching speed was $18.9 \mathrm{~km}$, but within the two recorded days, the army managed to walk almost $70 \mathrm{~km}$.

Keywords: military maps, engineers, Grodno, Tykocin, $18^{\text {th }}$ c. cartographers, military camps, Joseph-Gaspard Lambert de Guerin, Russian army

\section{Introduction}

Cartographers working in the Polish-Lithuanian Commonwealth did not only serve the Polish-Lithuanian kings and their subjects. The ability to create sketches, plans and maps was especially useful for enemies and allied armies operating in the territory of the Crown and the Grand Duchy of Lithuania. At the time, the geographical knowledge of army commanders was not supplemented with local information derived from residents or ordinary soldiers, and often the information was insufficient. Thus, the military engineers who surveyed the area were of paramount importance. We can mainly learn about their work from excellently preserved Swedish sources. The Scandinavian engineer corps produced many cartographic works depicting the land of the Commonwealth, from the turn of the $17^{\text {th }}$ c. up to the Great Northern War. ${ }^{1}$ The cartographic output of the Austrian and Russian armies, though only slightly smaller in scope, has not been studied thoroughly in the relevant subject literature to date.

1 Cartographica Poloniae 1570-1930: katalog źródet rękopiśmiennych do historii ziem polskich $w$ zbiorach szwedzkich, ed. U. Ehrensvärd, trans. M. Wawrzyńczak, Warszawa 2008. 
This article presents the capabilities of Russian military cartography during the first phase of the Great Northern War. ${ }^{2}$ Two maps kept at the Library of the Academy of Sciences in St. Petersburg provide the source material, and depict the area of the Biebrza river valley and its surroundings (entitled: Carte d'une partie de la Lithuanie et de la Pologne and Environs de Grodno et Ticochin). ${ }^{3}$ Both are identical with regard to the represented area, i.e., the Polish-Lithuanian borderland between Grodno and Tykocin. It is important to analyse them as their scale and the circumstances surrounding their creation confirm that they were made for military operations. As such, they constitute just some of the few preserved relics of military cartography. ${ }^{4}$

In the article I attempt to explore how cartography was used in Russian military operations in the early $18^{\text {th }} \mathrm{c}$. I evaluate the process of mapmaking in circumstances of war and the accuracy of the maps. For this purpose, I apply both geographical/historical and cartographic/mathematical methods of analysing old maps. ${ }^{5}$

In the light of previous research, we know little about these two cartographic items. We do not know when they were produced nor by whom; neither do we know whether they were really made to be used by

2 More information about Russian cartography until the end of the reign of Peter I can be found in: L. Bagrow, A history of Russian cartography up to 1800, ed. H. W. Castiner, Ontario 1975 , pp. $1-113$. In the $16^{\text {th }}$ and $17^{\text {th }}$ centuries, cartography mostly involved plans of fortresses and towns, as well as large-scale maps. Military cartographic activities predominantly referred to the south-western part of the Russian borderland. The mapping of Siberia, the Ukraine and the whole Russian Empire is a separate problem. V. Kivelson, Between all parts of the universe: Russian cosmographies and imperial strategies in Siberia and Ukraine in the age of Peter the Great, "Imago Mundi" 2008, vol. 60, no. 2, pp. 166-181.

3 Library of the Academy of Sciences, St. Petersburg, Sobrane Rukopisnykh Kart, Osn. Op. 286 and 288, respectively.

4 Cf. T. M. Nowak, Szwedzka mapa przemarszu wojsk Karola XII w 1708 roku z Kujaw na Biatoruś, in: Europa Orientalis. Polska i jej wschodni sasiedzi od średniowiecza po wspótczesność. Studia $i$ materiaty ofiarowane Profesorowi Stanistawowi Alexandrowiczowi w 65 rocznicę urodzin, eds. Z. Karpus, T. Kempa, D. Michaluk, Toruń 1995, pp. 197-209.

5 A. Konias, Metody oceny doktadności dawnych map, in: Teoretyczne $i$ metodyczne problemy wspótczesnej kartografii. Materiaty Ogólnopolskich Konferencji Kartograficznych, vol. 10, Lublin 1984, pp. 64-76; K. Nieścioruk, $Z$ metodyki badania map dawnych, "Annales Universitatis Mariae Curie-Skłodowska. Sectio B” 2004, vol. 59, pp. 273-281. 
the Russian army. Archivists have only calculated the scale, measured them and estimated the time of their production as the first half of the $18^{\text {th }} \mathrm{c}^{6}$ Aleksandr Sharymov referred briefly to these works in 2009. ${ }^{7}$ In Polish historiography, these valuable cartographic sources were mentioned three years later by Stanisław Alexandrowicz. ${ }^{8}$

\section{The creator of the maps}

It is not difficult to identify the author of both maps, for written on the reverse of one of them is the cartographer's name. It reads 'Lambert'. In my opinion, this was Joseph-Gaspard Lambert de Guerin (in Russian: Žozef Gaspar Lamber de Geren [Жозеф Гаспар Аамбер ле Герен]), a military engineer serving in the Russian army. The following facts support his authorship. Whoever created the maps added some uniquely decorated compass roses, ones pointing to the north-east. These objects, present on both analysed maps, correspond ideally to other works by the same author (Fig. 1). The arrow pointing north bears a two-headed eagle with its wings spread wide, which was the symbol of Tsarist Russia. Moreover, as stressed by Aleksander Sharymov, the handwriting found on these maps of the Polish-Lithuanian borderland matches the handwriting found on documents belonging to the engineer. ${ }^{9}$ Both maps are made in the same

6 In accordance with the calculations I have made, the scale of the Environs de Grodno et Ticochin is approx. 1 : 199 000, and the Carte d'une partie de la Lithuanie et de la Pologne, approx. 1 : 157 000. K. Łopatecki, Two maps of the Podlasie-Grodno borderline from 1706, "Kwartalnik Historii Kultury Materialnej" 2019, vol. 67, no. 4, pp. 481-504. The results differ from the findings of Russian archivists, who estimated the scale to be 1 : 111200 and 1 : 89 000, respectively. B. V. Aleksandrov, Opisaniye rukopisnykh kart XVIII v., khranyashchikhsya v Otdele rukopisnoy knigi Biblioteki Akademii nauk SSSR, in: V. F. Gnucheva, Geograficheskiy departament Akademii nauk XVIII veka. Prilozheniye II, Moskva-Leningrad 1946, p. 282.

7 A. Sharymov, Predystoriya Sankt-Peterburga. 1703 god. Kniga issledovaniy, SanktPeterburg 2009, pp. 555-558.

8 S. Alexandrowicz, Kartografia Wielkiego Księstwa Litewskiego od XV do potowy XVIII wieku, Warszawa 2012, pp. 205-206.

9 A. Sharymov, op. cit., pp. 555-558. 
way, the geographical names distorted in the French style, and they cover a similar geographical area, all of which suggest that they were compiled by the same man. ${ }^{10}$
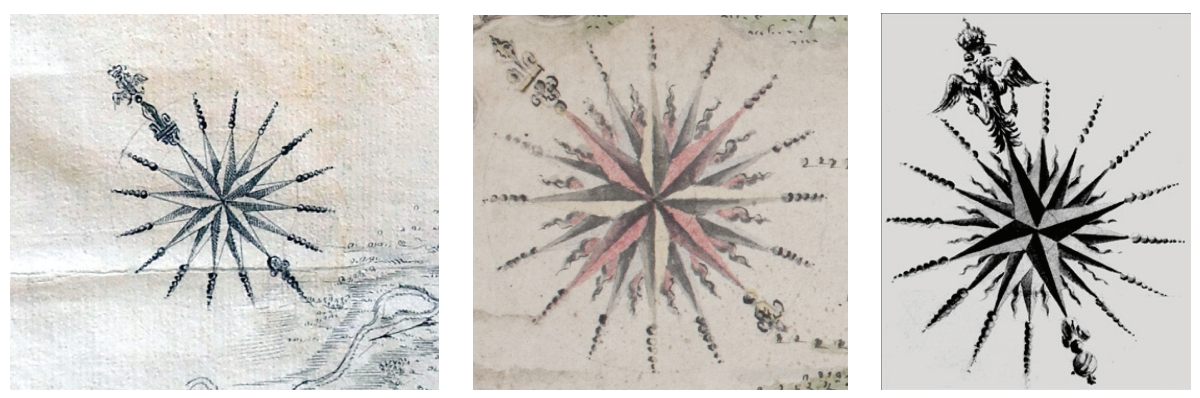

Figure 1. Compass roses on both maps compared to the rose added by Lambert to another cartographic work

Source: Library of the Academy of Sciences, St. Petersburg, Sobrane Rukopisnykh Kart, Osn. Op. 286, 288 and A. Sharymov, Predystoriya Sank-Peterburga. 1703 god. Kniga issledovaniy, Sankt-Peterburg 2009, p. 557.

The life of Joseph-Gaspard Lambert de Guerin was most eventful. ${ }^{11}$ He was born in France and joined the army of Peter I as early as in 1701, signing his military service contract in Warsaw with ambassador Grigorii Fedorovich Dolgorukov who was in residence at that time. In 1702, he took part in the siege of Noteburg, and following victory, he designed the

10 K. Łopatecki, Two maps..., pp. 491-499.

11 N. G. Ustryalov, Istoriya tsarstvovaniya Petra Velikogo, vol. 4, part 1, Saint Petersburg 1863, p. 230; M. Yu. Dankov, Baloven' fortuny. O zagadochnoy sud'be Lambera de Ger.ena, in: Trudy Gosudarstvennogo Ermitazha, vol. 32, Saint Petersburg 2006, pp. 113-122, 535; P. Krokosz, „Mata wojna”. Dziatania wojsk rosyjskich w Inflantach, in: Stan badań nad wielokulturowym dziedzictwem dawnej Rzeczypospolitej, vol. 3: Inflanty Polskie, eds. W. Walczak, K. Łopatecki, Białystok 2012, pp. 179-180; P. Krokosz, Twierdza Pietropawtowska w Sankt Petersburgu - miejsce militarne, miejsce sacrum, in: Twierdze osiemnastowiecznej Europy. Studia z dziejów nowożytnej sztuki wojskowej, vol. 2, ed. M. Trąbski, Częstochowa 2018, p. 111; J. Kazimierczyk-Kuncer, Z rozważań o rosyjsko-francuskim dialogu kulturowym XVIII wieku, “Acta Universitatis Lodziensis. Folia Litteraria Rossica” 2017, vol. 10 , p. 25. 
new Shlisselburg Fortress there. ${ }^{12}$ One year later, already ranked Engineer-General, he personally led the siege of Nyenschantz. He also helped choose the location for the construction of St. Petersburg, and designed the Peter and Paul Fortress. He was the first Frenchman to be awarded the Order of St. Andrew the Apostle by Peter I. In 1704, he led the successful siege and capture of Narva. In 1705-1706, he accompanied Peter I during his stay in Grodno on his campaign in the Commonwealth. Then, he received permission to go to Danzig, Berlin and Copenhagen in order to recruit engineers for the Russian army. However, he refused to return to Russia, which resulted in the tsar accusing him of desertion and ordering his arrest. Despite Lambert's repeated pleas for pardon, Peter I never annulled the sentence. In 1711, Lambert was arrested in Prussia, but he escaped from prison and went to Italy. He probably died in 1720 .

Lambert is characterised in greater detail as an engineer and a cartographer in a work written 1726 to 1727 titled $A$ conversation between three friends in a garden, ${ }^{13}$ that discusses the many foreigners serving in the Russian army. Much attention in the work was paid to Lambert de Guerin (called Lamberot). In response to the engineer's public complaints concerning the ungratefulness of the Russian authorities and their failure to pay his compensation, ${ }^{14}$ one of the characters reveals his real story. He explains that

12 We know of a case of Lambert's violation of military discipline during that campaign. On 17.08.1702, he had a duel with a frigate captain named Peter von Pamburh, and killed him. Pursuant to the military law, this called for the death penalty. However, Peter I released the engineer, whose skills (including designing the pontoon ferry) were essential for the military operations of the day. N. G. Ustryalov, Istoriya tsarstvovaniya Petra Velikogo, vol. 4, part 2: Primechaniya, Saint Petersburg 1863, doc. 46, p. 36; M. Yu. Dankov, Duel' na beregu Belogo morya v 1702 g. (O tragicheskoy gibeli gollandtsa Pitera fon Pamburkha), in: Dvinskaya zemlya, vol. 7: Materialy sed'mykh mezhregional'nykh obshchestvennonauchnykh istoriko-krayevedcheskikh Stefanovskikh chteniy, posvyashchennykh 300-letiyu so dnya rozhdeniya M. V. Lomonosova. 29-20 marta 2011 g., Kotlas 2013, pp. 66-75.

13 Razgovor mezhdu trekh priyateley, soshedshikhsya $v$ odnom ogorode, a imenno: Menarda, Talandra i Varemunda, "Russkiy vestnik" 1841, vol. 11-12, pp. 303-360 (especially 319, 323-327); A. Sharymov, op. cit., pp. 549-555.

14 We know of financial settlements between the Russian treasury and L. de Guerin for the years 1702-1703. In the first year, he received 420 roubles for coming to Russia and serving as an engineer. Probably, this was the compensation for the whole period of 


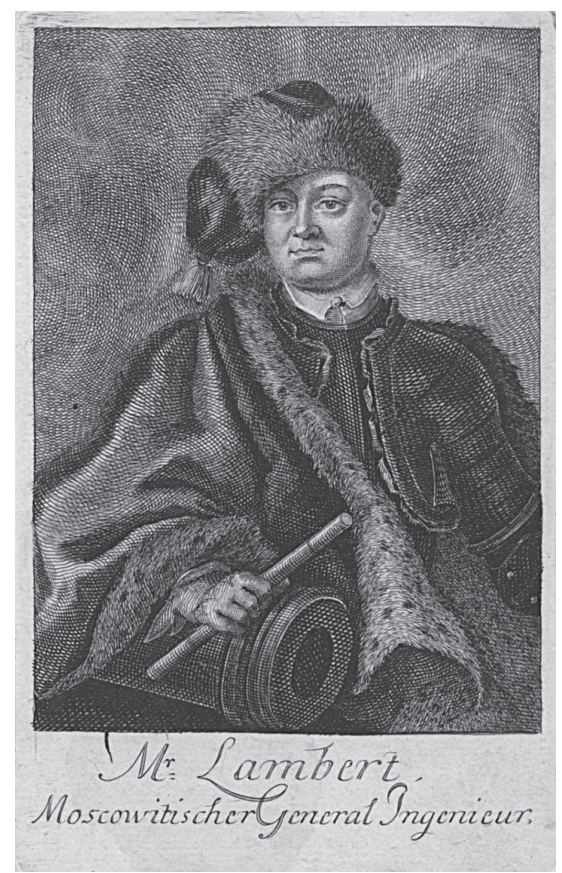

Figure 2. An image of Joseph-Gaspard Lambert de Guerin based on the works Neueröfneter Welt- und Staats-Spiegel: Worinnen die in der Europa published in The Hague in 1711 by the German engraver Martin Bernigeroth

Source: Neu-eröffneter Welt- und Staats-Spiegel: Worinnen die in der Europa, part 24, Haag 1711, page before the title page.

the man we are dealing with was not credible and indeed deserved to hang. His career began with the defeat at Narva (1700), following which the Russian authorities started to look for specialists all over Europe. Lambert took advantage of this fact, coming to the Polish court with excellent - but

service (from 1701). Another amount was the remuneration paid for an engineer-general: 400 roubles for the whole year of service. Prilozheniya Gosudarstvennyya rospisi 1680-1724 godov, in: P. Milyukov, Gosudarstvennoye khozyaystvo Rossii v pervoy chetverti XVIII stoletiya i reforma Petra Velikogo, Saint Petersburg 1905, p. 623 (item 5), 634 (item 2). There is no financial information available for the later periods. 
false - recommendations, presenting him as an outstanding military engineer. ${ }^{15}$ The Arkhangelsk campaign in 1702 proved that he was not competent in fortification and artillery operations, but his cartographic skills were appreciated (the source refers to him as a "painter"). ${ }^{16}$ Consequently, he was used as a maker of maps and plans and received the rank of engineer-general. Information about his cartographic skills was emphasized despite the subjective, and rather negative opinions circulating about him. Reference to the turn of the year 1706 is also important, for that was when Swedish troops advanced on the Russians located near Grodno. In that critical moment, Lambert deserted the army and headed to the west of Europe. ${ }^{17}$ On failing to obtain the financial rewards that he expected in the Old Continent, he travelled to the Ottoman Porte, where he offered to reveal information on the state of Russian fortifications and the weaknesses of the Russian army.

The attack against Lambert was the result of him revealing information about Russia while in France. In 1710, he even published a biography about Alexander Danilovich Menshikov, in which he presented the tsar in a bad light. ${ }^{18}$ The content of that work sheds no light whatsoever on the in-

15 At the time, French military engineers were regarded to be the best in Europe, and the fortification and siege art developed in the country of Louis $14^{\text {th }}$ was rated the highest. See J. Ostwald, Vauban under siege: engineering efficiency and martial vigor in the war of the Spanish succession, Leiden-Boston 2007; Ch. Duffy, The fortress in the age of Vauban and Frederick the Great 1660-1789, London-Boston 2015, pp. 1-97.

16 It must be stressed, however, that the use of the term "painter" may depreciate Lambert's cartographic skills. It highlights his artistic skills, not his scientific knowledge and practical experience. More information on the way cartographers were identified with painters in the $16^{\text {th }}$ and the early $17^{\text {th }}$ centuries can be found in: M. Gębarowicz, Początki malarstwa historycznego w Polsce, Wrocław-Warszawa-Kraków-Gdańsk 1981, pp. 17-27.

17 Actually, this was not the only case. The aversion of French soldiers to fighting Charles XII (who was admired all over Europe) is discussed in: J. D. Hultman, O panowaniu Karola XII króla Szwecji, ed. and trans. W. Krawczuk, Kraków 2015, p. 109. At the same time, one of the tsar' s closest associates, Andreas Andreaszon Winius, also left the army and escaped from Grodno to Prussia in March 1706. A. Slesarenko, Armia rosyjska w operacji grodzieńskiej z 1705-1706 roku, "Wschodni Rocznik Humanistyczny" 2013, vol. 9, p. 68.

18 [J-G. Lambert,] Le prince Kouchimen, histoire tartare, et Don Alvar del Sol, histoire napolitaine, Paris 1710 (Kouchimen is an anagram of Alexander Danilovich Menshikov). Cf. R. Tavernier, Russia and the low countries: an international bibliography, 1500-2000, 
tellectual horizons of its author. However, he certainly was knowledgeable about cartography. As he evaluates the vastness of Russia in his narrative, he verifies the data presented on existing printed maps. ${ }^{19}$

In evaluating Lambert as a military cartographer, one needs to accept that he was neither outstanding, nor even good. The fundamental mistakes he made are described in greater detail in point 4 . However, his way of compiling medium-scale maps was better than the level found in contemporary Russian military works. This can be assessed through comparing the Environs with the oldest Russian map of this kind, drawn up in a scale useful for military operational activities. ${ }^{20}$ This being a cartographic relic prepared by Maksim Tsyzyrev in 1701 (Fig. 3), presenting the Daugava river with the main fortresses (Vitebsk, Polotsk) and nearby settlements marked. ${ }^{21}$ The map was compiled in accordance with instructions ordering a secret reconnaissance mission. On this basis, a map covering Vitebsk and the whole of the Upper Daugava river to its source had to be produced, one on which had to be incorporated the state border, and included the towns and settlements located along the river. ${ }^{22}$

This work of Russian cartography was compiled in the traditional manner, with characteristic decorations, disproportionately big towns and wide rivers. The exaggerated symbols of towns were merely decoration; they did not indicate the true state of fortifications. ${ }^{23}$ The map had no geographical directions marked, meaning no compass was used when preparing it. It did

Groningen 2000, p. 390, item A231. The authorship of this work is attributed to François-Timoléon de Choisy by N. A. Kopanev, N. P. Kopaneva, Pervoye zhizneopisaniye knyazya Menshikova: k voprosu ob avtorstve, "Menshikovskiye chteniya" 2010, vol. 8, pp. 95-102.

19 [J-G. Lambert,] op. cit., p. 16.

20 T. M. Nowak, Polska artyleria, inżynieria i kartografia wojskowa XVII w. - teoria i praktyka, "Studia i Materiały do Historii Wojskowości" 1979, vol. 22, p. 117, concluded that the scale of the maps was from 1:600 000 to $1: 200000$, respectively.

21 V. Kivelson, Cartographies of Tsardom. The land and its meanings in seventeenth century Russia, Ithaca-London 2006, pp. 32-33; A. Sapunov, Reka Zapadnaya Dvina s kartami, planami i risunkami, Vitebsk 1893, pp. 501-506 (reproduction on page 52).

22 V. Kivelson, Cartography..., p. 87.

23 K. Łopatecki, Okoliczności powstania i przydatność wojskowa mapy Descriptio Ducatus Polocensis Stanistawa Pachotowieckiego (1580), “Terminus” 2017, vol. 19, no. 1, p. 87 (Fig. 1b), 94 (Fig. 2). 
not have a scale, either, and did not present the complex topography of the area. It merely symbolically represented forest areas, which should rather be identified with tree-covered river banks; the complex catchment area of the Daugava river as well as the road network are missing. It is clear that the work was compiled during a river trip, without any land terrain survey. Works by Joseph-Gaspard Lambert de Guerin were definitely on a higher level. However, if we were to compare them with the cartographic works completed in situations of peace, contemporary Russian maps were of a much better quality than the maps showing the environs of the Biebrza river. ${ }^{24}$

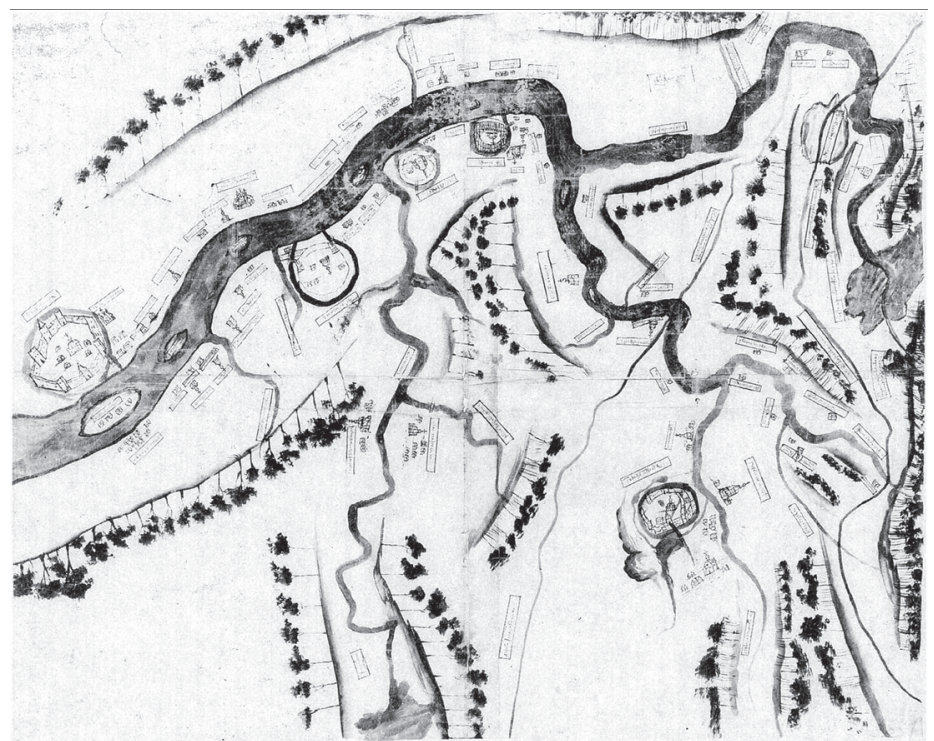

Figure 3. Map of the surroundings of the Daugava river drawn up by Maksim Tsyzyrev in 1701. Rossiuskiy Gosudarstvennyy Arkhiv Drevnikh Aktov, f. 192, op. 1, no. 1, dz. 2, respectively

Source: V. Kivelson, Cartographies of Tsardom. The land and its meanings in seventeenth century Russia, Ithaca-London 2006, p. 33.

24 The works by Semon Ulyanovich Remezov, who compiled an atlas of Siberia in the years 1699-1701, were of very high quality. S. U. Remezov, Prilozheniye $k$ chertezhnoy knige Sibiri, sostavlennoy Tobol'skim synom boyarskim Semenom Remezovym v 1701 g. I. Tekst. II. Ukazatel', Saint Petersburg 1882. 


\section{The circumstances of the map making}

Within less than five years of his service in the Russian army, Lambert as an engineer-general created the basis for the development of modern military cartography. He created, or rather transferred to Russia, the standards applicable in the west of Europe and later codified in 1716 by Peter I in his Military code (Ustav voinskii). In light of that document, the use of cartography in military operations was basically reduced to two instances. First, it was the general quartermaster's task to accommodate the travelling troops, and that was to be preceded by the preparation of a map. ${ }^{25}$ Second, maps should be compiled during the army's march through territories unknown or hostile and at risk of enemy attack. Then, a day before the troops arrival, reconnaissance should be performed by engineers assigned by the quartermaster, and here with a cavalry escort. They were expected to draw the entire area on a field map, including the main terrain elements and all road routes that could be chosen. ${ }^{26}$

Undoubtedly, the two maps currently held at the Library of the Russian Academy of Sciences were used for the latter purpose. ${ }^{27}$ The question remains as to when and in what circumstances they were created, and why there are two similar yet not identical works. In order to answer this question, we need to analyse their content. Both works represent the area between Grodno and Tykocin, which - given Lambert's life story - clearly shows that they were produced not later than in March/April 1706.

There is one more piece of evidence connected with estimating the date of Lambert's maps. Both works present a bridge on the Biebrza River called "Pont Comanse". This was located in the middle of the section between Goniądz and the mouth (inlet) of the Biebrza at the Narew. Zygmunt

25 An example of that: T. M. Nowak, Szwedzkie źródto kartograficzne ukazujące trase przemarszu armii M. G. de la Gardie ze Żmudzi na Mazowsze w 1655 r., "Studia i Materiały do Historii Wojskowości” 1988, vol. 30, pp. 321-350.

${ }^{26}$ Kodeks wojskowy Piotra I z 1716 roku, eds. P. Krokosz, K. Łopatecki, Kraków-Oświęcim 2016, pp. 106, 115.

27 L. Bagrow, op. cit., p. 134. We know of analogous maps of the march made by Swedish troops in 1708. See T. M. Nowak, Szwedzka mapa..., pp. 197-209. 
Gloger described its remains in the early $20^{\text {th }}$ c.: near the village of Sośnia there was a sandy island called the "Swedish bridge". ${ }^{28}$ Indeed, Swedish troops crossed the Biebrza at that point in 1708, with the town being erroneously recorded as "Zozna". ${ }^{29}$ The construction was initiated by Stanisław Antoni Szczuka in 1704 on his estate, and one year later, work was at quite an advanced stage. The structure was 12 cubits (ells) wide, and its length was estimated as 1000 steps..$^{30}$ Analysis of correspondence preserved from that time shows that the work on the bridge was nearly completed by the middle of March 1706. Due to its strategic nature, the Russian army had taken over the investment from Szczuka at the turn of 1706. However, the work was of a poor quality and was probably limited to expediency and the need to utilize the structure for current purposes. In the early spring, the investment was again taken over by Szczuka, who had hired craftsmen and workers for this purpose. ${ }^{31}$ The bridge was crossable from the end of 1705 and constituted one of the main routes used by Russian troops in their maneuvers and food requisition; something which frustrated the nobility, who demanded construction on the bridge be stopped or, preferably,

28 Z. Gloger, Dolinami rzek. Opisy podróży wzdtuż Niemna, Wisty, Bugu i Biebrzy, Warszawa 1903, p. 209.

29 [Nieschawa-Johannisburg-Grodno-Sabloze,] Krigsarkivet, Sveriges Krig, 5:47. Erroneously spelled "Szozna" in the work: T. M. Nowak, Szwedzka mapa..., p. 204. A fragment of this map is presented in Fig. 8.

${ }^{30}$ M. Skrodzki to [S. A. Szczuka], Szczuczyn 12.03.1705, Archiwum Główne Akt Dawnych w Warszawie (further: AGAD), Potocki Public Archive, sygn. 163a, vol. 38, pp. 313-317; I. Grochowska, Stanistaw Antoni Szczuka - jego dziatalność w ziemi wiskiej 1682-1710, Warszawa 1989, pp. 139, 214-215; J. Kloza, J. Maroszek, Dzieje Goniadza w 450 rocznice praw miejskich, Białystok-Goniądz 1997, pp. 59-61, 96-97; J. Wiśniewski, Podkanclerzy Stanistaw Antoni Szczuka a geneza, rozrost i rozpad dóbr szczuczyńskich, in: Studia i materiaty do dziejów powiatu grajewskiego, vol. 1, eds. M. Gnatowski, H. Majewski, Warszawa 1975, p. 262.

31 M. Skrodzki to S. A. Szczuka, Szczuczyn 12.03.1706, AGAD, Potocki Public Archive, sygn. 163a, vol. 38, p. 209; the former to the latter, Szczuczyn 17.03.1706, ibidem, pp. 213-214; the former to the latter, Wysokie [no specific date provided] 03.1706, ibidem, pp. 233-234; M. Skrodzki to A. Szczeniawski, Borsukowo 4.01.1706, ibidem, p. 222. 
destroyed. ${ }^{32}$ Given the data from Lambert's biography and the above-mentioned construction of the bridge, it follows to assume that both maps were created within the first three months of 1706.

At the turn of 1706, the so-called Grodno Campaign was underway, followed by the spectacular retreat of the entire Russian army from Grodno to avoid total defeat. These events need to be briefly discussed. ${ }^{33}$ In the autumn of 1705, Peter I decided to assemble the Russian army near Grodno, allowing him to harass the Polish land so as to force the Swedish army, gathered near Warsaw for the coronation of Stanisław Leszczyński (on 4 October 1705), ${ }^{34}$ on to the defence. It was planned to employ Saxon, Polish-Lithuanian, Russian and Cossack troops to encircle the Swedish forces stationed in the central part of the Crown for the winter campaign. ${ }^{35}$ The main body was to be comprised of the troops stationed near Grodno, where by 30 November 1705, about 42000 Russian soldiers and 12 000-13 000 Saxon and Polish soldiers were quartered; these troops being additionally bolstered by cannon units numbering 110 artillery pieces. $^{36}$

32 M. Skrodzki to S. A. Szczuka, Bronowo 9.03.1706, AGAD, Potocki Public Archive, sygn. 163a, vol. 38, p. 225; I. Grochowska, op. cit., p. 214.

33 V. I. Baskakov, Severnaya voyna 1700-1721 gg. Kampaniya ot Grodna do Poltavy 1706-1709 gg., Saint Petersburg 1890, pp. 93-184 (description of the area of the military operationss); P. Krokosz, Rosyjskie sity zbrojne za panowania Piotra I, Kraków 2010, pp. 323-326; A. Slesarenko, op. cit., pp. 61-65; B. B. Kafengauz, Severnaya voyna i Nishtadt.skiy mir (1700-1721), Moskva-Leningrad [1944], pp. 26-30; A. Kamiński, Początki antyszwedzkiego sojuszu. Ze stosunków polsko-rosyjskich 1704-1706, "Przegląd Historyczny" 1969, vol. 60, no. 2, pp. 297-300; Z. Chmiel, Military actions on the territory of the Polish-Lithuanian Commonwealth in 1706, "Codrul Cosminului" 2015, vol. 21, no. 2, pp. 322-323; A. Kamiński, Przeciwko Szwedom i Leszczyńskiemu. Dziatania wojsk rosyjskich na terenie Polski w 1705-1706 roku, "Studia i Materiały do Historii Wojskowości" 1966, vol. 12, no. 2, pp. 239-242; J. Wimmer, Wojsko Rzeczypospolitej w dobie wojny pótnocnej, Warszawa 1956, pp. 304-305.

34 M. Sawicki, Elekcja i koronacja Stanistawa Leszczyńskiego w świetle polskich gazet ulotnych, in: Wesela, chrzciny i pogrzeby w XVI-XVIII w., ed. H. Suchojad, Warszawa 2001, pp. 109-114.

35 O. Sjöström, Fraustadt 1706, ett fält färgat rött, Lund 2009, pp. 70-72.

36 M. Skrodzki to [S. A. Szczuka], Sidra 14.09.1705, AGAD, Potocki Public Archive, sygn. 163a, vol. 38, p. 403. It contains the information that the first part of Russian forces 
The plans of Peter I and Augustus II failed. Following Stanisław Leszczyński's coronation, the Swedish army stationed near Warsaw set out north-eastwards, toward the enemy's camp. ${ }^{37}$ After fourteen days of strenuous march, on 25 January, the 18 000-strong army of Charles XII, bolstered by Polish units, crossed the solidly frozen Neman river near Grodno. This manoeuvre completely surprised the allied forces. Despite their huge numerical advantage, they were afraid to fight a decisive battle against a much smaller but perfectly trained Swedish army. As a result, they adopted a defensive technique: they fortified the town and the adjacent camp. This was Augustus II's thinking, who decided that in the face of the aggressive moves of Charles XII, it was necessary to concentrate 45 Russian battalions in Grodno, and the Tykocin commander was ordered the fortress to be defended at all costs. ${ }^{38}$ The king left Grodno at the last possible moment with 4000 cavalrymen, who could not be successfully used for the defence of the fortification. The defensive plan would prove to be a partial success: the Swedish army did not lay siege to the town. However, the Swedes used their operative initiative and took full control over the territory, cutting off supplies to the Russian camp (the only road held by the Russians led to Tykocin). Swedish army's headquarters was set up at Żołudek, $87 \mathrm{~km}$ east of Grodno. This location blocked the relief forces organized by Peter I from near Minsk.

It seemed that Peter I was doomed to disaster, especially that on 13 February, the Battle of Wschowa was fought, where the Swedes defeated the Saxon and Russian troops, confirming their advantage both with regard

arrived in Grodno. Four regiments and two thousand Cossacks crossed over to the left bank of the Neman river and set up a camp by the Lasosna river. Those forces began to build a bridge half a mile downstream of Grodno itself.

37 The army crossed the Vistula covered with ice and straw on 9 January 1706. But interestingly, Charles XII did not choose to reach Grodno along the shortest route, which led through the Biebrza river valley. That would have required the siege and capture of Tykocin, and then travelling in boggy areas. Instead, an easier but longer route was chosen, leading eastward through Węgrów. The troops crossed the Bug river at Osnówka, and the Narew river at the height of Brańsk. Then, the army went straight towards Grodno. J. D. Hultman, op. cit., pp. 106-108.

${ }_{38}$ N. G. Ustryalov, Istoriya, vol. 4, part 2: Primechaniya, dok. 360, p. 394; Z. Anusik, Karol XII, Wrocław-Warszawa-Kraków 2006, pp. 139-141. 
to tactics and the level of their soldiers' training. ${ }^{39}$ The camp near Grodno was plagued with hunger and disease, and desertion increased. ${ }^{40}$ When the victorious troops under Carl Gustaf Rehnskiöld reached the main army, the prospect of taking Grodno seemed most real. Aleksander Menshikov's corps left Grodno in February for Tykocin and subsequently further east. The remaining forces were commanded by Field Marshal Georg O'Gilvy. The tsar required that his chief commander retreat with the army, even at the cost of abandoning the artillery, supplies and the wagon trains.

O'Gilvy and his team executed the operation perfectly, taking advantage of the climatic conditions. The withdrawal of the troops was correlated with the thaw (with ice floes on the Neman river), thereby limiting the possibility of being pursued. Tykocin, still occupied by the Russians, would be the first stop. ${ }^{41}$

First, on 22 March or 2 April, Colonel Novikov set off toward Tykocin with 2900 injured and sick soldiers. The following day, two other brigades set off, while the rest of the army, formed into two corps, began the march on 24 March or 4 April. Within the next two days, all the Russian troops had gone south-westward, abandoning a part of the wagon trains, the camp itself, having left the artillery to sink (70-75 cannons). The army arrived in Tykocin on 29 March or 9 April, and on 4/15 April, they were at Brest Litovsk, after which they continued their march toward Kiev (see Table 1). A successful pursuit was an impossibility for the Swedish army was dispersed (divided into three regiments), and in addition, the ice floe on the

397400 Saxon and Russian troops died, with twice as many soldiers taken captive (some were killed), with only 400 soldiers lost on the Swedish side. O. Sjöström, Bitwa pod Wschowa 1706. A potem pole bitwy zamienito się na czerwono, trans. W. Łygaś, Zabrze-Tarnowskie Góry 2012, pp. 243-248; Z. Chmiel, op. cit., pp. 323-325.

40 When Russian troops were stationed in Grodno, about 8000 soldiers (about 33 percent of the army) died of hunger, disease, or cold. J. Basista, Fraustadt-Grodno Massacres (1706), in: Atrocities, massacres, and war crimes: An Encyclopedia, vol. 1: A-L, ed. A. Mikaberidze, Santa Barbara 2013, s. 190.

41 This was possible thanks to the resolute decision of the field marshal, who prevented the blowing up of the Tykocin fortress, demanded by Mienszykow. G. O'Gilvy to Peter I, Grodno 17.02.1706, in: N. G. Ustryalov, Istoriya, vol. 4, part 2: Primechaniya, dok. 369, p. 397. 
Neman river had destroyed the only bridge held by the Swedes. The thaw also hampered any good chance of pursuit. ${ }^{42}$

Both the analysed maps are testimony to the cartographic preparation for the logistically complicated and dangerous withdrawal of the Russian army from Grodno in the direction of Tykocin. Finding two or three parallel routes along which the troops, wagon trains and artillery could move was of key importance. ${ }^{43}$ This was essential due to the need to shorten the marching columns and reduce the disorder arising from the river crossing. ${ }^{44}$ The attempts recorded on the maps proved somewhat of a failure: the route leading along the left bank of the Biebrza river was impassable because of problems with fording the Netta or Biebrza at the height of this tributary. Two routes for crossing the Brzozówka were planned, with only one being chosen along the upper course of the Biebrza river. These findings forced the army to choose one more way for the other wing to march along. There was only one choice: the route had to run to the east of the first, closer to the Swedish forces and their allied Lithuanian-Polish units (Fig. 9). It also had to cross the Brzozówka river; and for that reason possible routes were marked on the map. ${ }^{45}$

42 W. F. Rakowski, Pamiętnik Wielkiej Wojny Pótnocnej, eds. M. Nagielski, M. Wagner, Warszawa 2002, p. 42; N. G. Ustryalov, Istoriya, vol. 4, part 2: Primechaniya, dok. 384-387, pp. 407-410; P. Krokosz, Rosyjskie sity..., pp. 326-327; A. Slesarenko, op. cit., pp. 65-70; A. Kamiński, Przeciwko Szwedom..., pp. 243-248.

43 The importance of making several march columns is explained in: A. L. Oelsnitz, O bagażach wojska w polu będącego, ed. K. Łopatecki, Oświęcim 2014, pp. 192-228. The author makes use of the operational activities of the marshal of France, François Henri de Montmorency-Bouteville, duc de Piney. See J. de Beaurain, Histoire militaire Du Duc De Luxembourg [...] en Flandre, depuis l'année 1690 jusqu'en 1694 inclusivement, vol. 1-5, A La Haye [The Hague] 1756-1758.

44 It is noteworthy that in 1702 , the Swedes crossed the Narew and Neman rivers at the height of Tykocin and Grodno in two march columns. Riksarkivet, Wijksamlingen, Kartor och ritningar, 0039 : 00002.

45 The Brzozówka river could render an army's efficient march difficult or even impossible. This is visible in the march of the Swedish troops in 1708, which had to considerably deviate from the original route in order to find a good place to cross the river. T. M. Nowak, Szwedzka mapa..., pp. 205, 207-208. 
The evaluation of feasible marching routes forced the Russian high command to consider destroying the majority of the artillery and wagon trains. However, reconnaissance assured the commanders that it was indeed possible to reach Tykocin in the early spring thereby allowing them to determine the optimum marching route. Reconnaissance and preparation for crossing the Narew river was even more vital. And here it was found that the army could ford this obstacle at three sites (Zajki, Łazy and Tykocin see Fig. 4 and 5). This was of key importance for the second stage of the journey, whose destination was Brest Litovsk. It was while crossing the Narew that the Russian army faced the greatest danger of being destroyed.

The final preparation began 13 days before the march. On 22 March, Field Marshal Georg O'Gilvy sent 200 Vlachs and dragoons to Sidra in order to reconnoitre the area and to gather food. The same occurred on the territories reproduced on the maps. ${ }^{46}$ The preserved protestations show that the looting was thorough and conducted in conjunction with a scorched earth policy. This happened on the Sidra estate, where not only were villages pillaged and burnt, but those living there were held to ransom and the local palace was plundered. ${ }^{47}$

On 3 April, a proclamation set out the specific regulations covering the march. The army was to perform a four-day strenuous march in the direction of Tykocin. For this an additional horse had be added to each of the wagons (two-horse half-covered wagons); limitations were imposed on personal belongings and additional carts. It was announced that the commander of the Tykocin fortress would show the troops where to cross the Narew, and they would ford day and night. ${ }^{48}$ We have the route covered by one wing of the

46 G. O’Gilvy to Peter I, Grodno 26.03.1706, in: N. G. Ustryalov, Istoriya, vol 4, part 2: Primechaniya, dok. 381, p. 406; J. Wiśniewski, Dzieje osadnictwa w pow. augustowskim od XV do końca XVIII wieku, in: Studia i materiaty do dziejów Pojezierza Augustowskiego, ed. J. Antoniewicz, Białystok 1967, p. 204.

47 [Protestacja podkanclerzego Szczuki na choragwie wojska sapieżyńskiego], in: Akty Vilenskoy arkheograficheskoy komissii, vol. 7: Akty Grodnenskogo gorodskogo suda, Vil'no 1874, pp. 458-461.

48 Žurnal vystupleniya Russkikh voysk iz Grodno v 1706 godu [Журналь вылтупленія Русскихъ войскъ изъ Гродно въ 1706 году], in: N. G. Ustryalov, Istoriya, vol. 4, part 2: Primechaniya, dok. 387, pp. 409-410; S. K. Szwykowski to K. S. Radziwiłła, Kraków 18 
army, which went via Sidra, Sokółka and Knyszyn to Tykocin (Fig. 9), and then via Brest Litovsk to Kiev. Therefore, we are able to determine the speed of their march. The average daily distance covered by the army was $18.9 \mathrm{~km}$ (Table 1). Research into the marching speed of an entire army in Central and Eastern Europe has yet to be undertaken. However, it is worth pointing out that actually marching speeds were quite high: during the reign of Stefan Batory, the Polish-Lithuanian army could march $14 \mathrm{~km}$ a day on average. ${ }^{49}$ The army marched the fastest between Tykocin and Bielsk Podlaski: $64.8 \mathrm{~km}$ within the course of two days..$^{50}$ Their pace of march in the first two sections also deserves recognition. Although the journey was a day longer than the planned route to Tykocin, the first section took the army through forest, while the second involved the difficult crossing of the Narew river.

Table 1. The route of (one wing of) the Russian army: Zhurnal" vystupleniya Russkikh" voysk" iz" Grodno v" 1706 godu, in: N. G. Ustryalov, Istoriya tsarstvovaniya Petra Velikogo, vol. 4, part 2: Primechaniya, Saint Petersburg 1863, pp. 409-410

\begin{tabular}{|c|c|c|c|c|}
\hline Date & Town & $\begin{array}{c}\text { Distance as the } \\
\text { crow flies }(\mathbf{k m})\end{array}$ & $\begin{array}{c}\text { Marching } \\
\text { distance }(\mathbf{k m})\end{array}$ & $\begin{array}{c}\text { Daily marching } \\
\text { speed (km) }\end{array}$ \\
\hline $24.03 / 4.04$ & Grodno & & & \\
\hline $26.03 / 6.04$ & Sokółka & 27.1 & 36.7 & 18.35 \\
\hline $29.03 / 9.04$ & Tykocin & 53.5 & 61.6 & 20.5 \\
\hline $31.03 / 11.04$ & Bielsk Podlaski & 56.4 & 64.8 & 32.4 \\
\hline $4.04 / 15.04$ & Brest Litovsk & 82.7 & 102 & 25.5 \\
\hline $13.04 / 24.04$ & Kovel & 119.2 & 131 & 14.6 \\
\hline
\end{tabular}

IV 1706, in: Przy boku króla Stanistawa Leszczyńskiego (1706-1709), vol. 1: Wyprawy do Saksonii $i$ Litwy $w$ latach 1706-1708. Listy królewskich sekretarzy Samuela Kazimierza Szwykowskiego i Jozafata Michata Karpia oraz fragmenty z gazet pisanych i diariuszy, ed. J. Dygdała, Warszawa 2018, p. 29.

49 M. Wrede, Itinerarium króla Stefana Batorego 1576-1586, Warszawa 2010, p. 42.

50 This was a very fast pace. The allegedly rapid campaign of Krzysztof "Thunder" Radziwiłł of 1579 obtained an average daily speed of $21.6 \mathrm{~km}$. K. Eopatecki, The military expedition of Krzysztof Radziwitt "Piorun" to Livonia in the winter of 1579, "Zapiski Historyczne" 2018, vol. 83, no. 1, p. 54 . 


\begin{tabular}{|c|c|c|c|c|}
\hline Date & Town & $\begin{array}{c}\text { Distance as the } \\
\text { crow flies }(\mathbf{k m})\end{array}$ & $\begin{array}{c}\text { Marching } \\
\text { distance }(\mathbf{k m})\end{array}$ & $\begin{array}{c}\text { Daily marching } \\
\text { speed (km) }\end{array}$ \\
\hline $28.04 / 11.05$ & Polonne & 231.8 & 258 & 17.2 \\
\hline $8.05 / 21.05$ & Kiev & 216.6 & 232 & 23.2 \\
\hline
\end{tabular}

In my opinion, the fact that a huge number of soldiers were present in and around Grodno from the second half of September 1705 onwards necessitated a cartographic survey of the area. The first sketches, including the Carte d'une partie de la Lithuanie et de la Pologne, could have even been produced in the winter, as a result of the huge undertaking that was the delivering of supplies to the army stationed in Grodno. ${ }^{51}$ Then Tykocin constituted a supply meeting point for produce and contributions from distant parts, whence they were delivered to Grodno in convoys. ${ }^{52}$ The final version of the Environs de Grodno et Ticochin map was produced for the needs of the retreat of the whole Russian army from Grodno and considerably contributed to the success of the operation. It was probably produced in March or the beginning of April 1706. Apart from the two existing maps showing the routes between Grodno and Tykocin, some other, now unknown works were also created, showing an alternative way via Sokółka and Knyszyn, something partially suggested in both sources (Fig. 9). After completing these tasks, Lambert left the army and headed to Danzig. From there, he wrote a farewell letter to the tsar, dated 12 May 1706. ${ }^{53}$ Perhaps, though this is mere speculation, the French cartographer left the army before the completion of all the possible routes on the map, including the way via Knyszyn and Sokółka.

51 For instance, Jerzy Wiśniewski (Dzieje osadnictwa..., p. 204) found information that some Russian troops were marching through Rajgród on 15 January 1706.

52 For example, food was brought to Tykocin from the Brest Litovsk poviat under the sejmik resolution forced by the Russian military. Manifest Jaśnie WIelmożnego JM Pana Wtadystawa Sapiehy wojewody minskiego, Brześć Litewski 16 I 1706, Natsyyanal'Ny histarychny arkhiw Byelarusi (h. Minsk), 1705, depiction 1, No. 118, ff. 1763-1764.

53 A. Sharymov, op. cit., pp. 548, 551. 


\section{How the maps were made and topographic analysis}

The first map, Carte d'une partie de la Lithuanie et de la Pologne, shows the course of the Biebrza river up to its mouth at the Narew. I estimate that the survey for this map began from Tykocin and continued northwards or north-eastwards. The area between the Narew river (from Tykocin) and the Biebrza, right up to the mouth of the Brzozówka river, was surveyed very well. A relatively dense road network was shown in this area. A road running from Tykocin and branching off to Szorce and Trzcianne was presented. The first one led to Łazy, Zajki (and farther to Brzeziny located near the mouth of the Biebrza river at the Narew, though the town of Brzeziny was not recorded on the map) and to Goniądz. The second one divided once again. Two roads went towards the east, across the Brzozówka river, with their further course not recorded..$^{54}$ The third road led to Goniądz, Krzecz, and branched off toward Smogorówka and Mikiciny. In my view, reproducing the upper and middle course of the Biebrza above the Brzozówka river was based on oral information; the same applied to the road leading to Grodno (Fig. 4). This is proved by the highly incorrect spatial representation, which was corrected on the other map (Fig. 5).

The key puzzle remains to be solved. The directions on the surveyed area are very poorly oriented. Instead of flowing from east to west, the Narew river is directed from south to north, while the Biebrza, instead of running towards the south or south-west, runs from east to west. This aberration can be explained if we assume that the map was compiled in a northern or north-western orientation, with the rose compass added later, and transferred from another map. The northern orientation would show a better organization of the river courses and the location of towns. Transferring the southern area to the other map, Environs de Grodno et Ticochin, led to total spatial decomposition, as is visible on the distortion grid (Fig. 5 and 6).

54 The Russian troops moving from Grodno towards Sidra, Sokółka and Knyszyn on 29.03/09.04.1706 went along these roads - see Table 1 . 


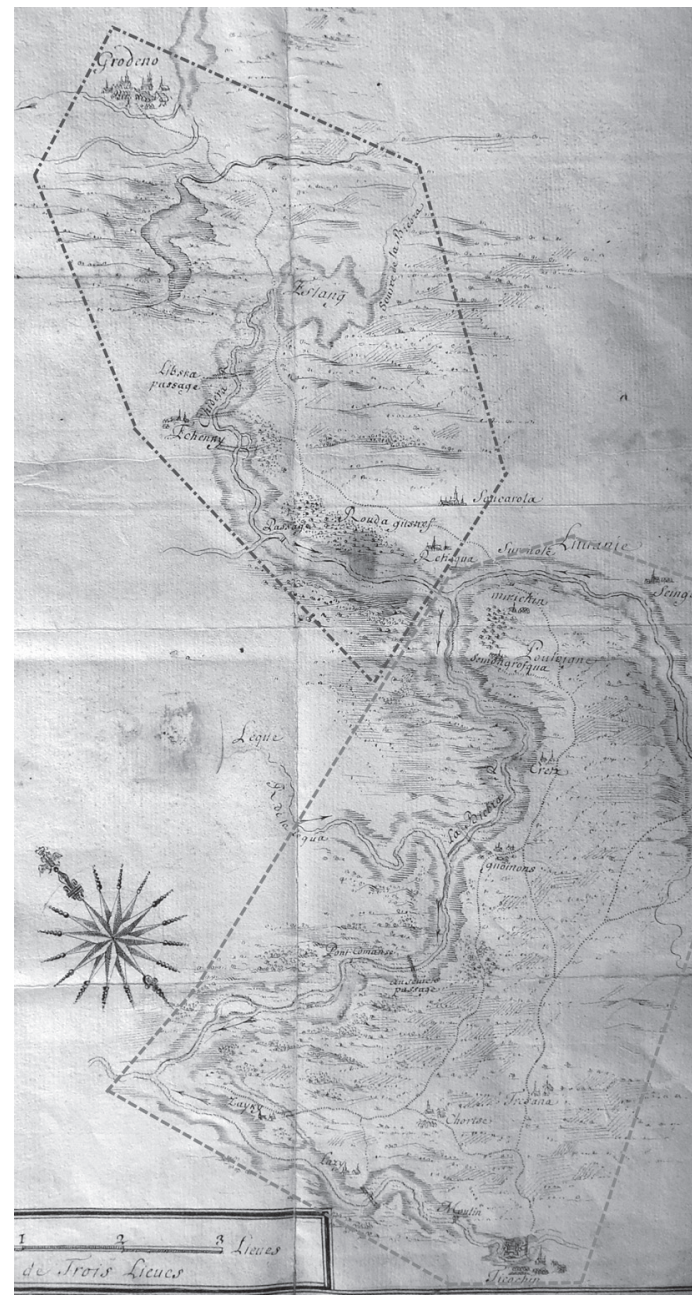

Figure 4. The method of preparing the Carte d'une partie de la Lithuanie et de la Pologne map by Joseph-Gaspard Lambert de Guerin: 1) ——— the area surveyed personally; 2) - $-\bullet$ the area reconstructed on the basis of oral accounts

Source: the author's own study based on: Library of the Academy of Scienses, St. Petersburg, Sobrane Rukopisnykh Kart, Osn. Op. 286.

The Environs presents a much bigger area. In order to reconstruct the way the map was drawn up, I have prepared a distortion grid with a $5 \mathrm{~km}$ 
mesh based on 35 stable points using the MapAnalyst program (Fig. 5). ${ }^{55}$ The results show that the map was produced the most carelessly. The north-eastern area from Grodno through Tykocin and right up to the Brzozówka river is presented the most accurately. The distortion grid justifies the hypothesis that the Environs was created as a result of the juxtaposition of at least three maps such as the Carte d'une partie de la Lithuanie et de la Pologne (Fig. 4). The greatest distortions occur at the boundaries of these juxtaposed maps (Fig. 5 and 6).

Therefore, we need to modify the hypothesis advanced by Stanisław Alexandrowicz, who considered the Carte to be a sketch or a preliminary (formative) stage in the production of the Environs. ${ }^{56}$ Some of the information from the first map, and here developed on the basis of oral accounts, was revised and not included in the Environs. For example, the course of the Neman river was corrected, two (not four) crossings over the river were marked near Lipsk (a third route led towards the river but did not indicate the possibility of being able to cross over). The river courses were also modified. A lake or a bog called Eslang was removed. New crossings were added, and two towns (Rouda Gustrof and Retisqua), which are not included on any of the maps I know of, were erased. Many new settlements were included on the route. Unfortunately, the lower course of the Biebrza river on the Carte was almost identically copied, with only few modifications, together with the terrible mistake in spatial orientation. ${ }^{57}$

The third surveyed area was the road leading from Grodno to $\mathrm{Au}$ gustów, Rajgród and Tykocin. This survey was unsuccessful (see point 3), probably due to hydrological and climatic factors. There was definitely a reason why Karol Perthees described this area as one of immense mud

55 The use of the MapAnalyst program to study old maps: K. Strzelecki, Wykorzystanie aplikacji MapAnalyst w badaniu dawnych map, "Słupskie Prace Geograficzne" 2016, vol. 13, pp. 213-227; W. Żyszkowska, The numerical analysis of a lost old-days manuscript map, "e-Perimetron" 2013, vol. 8, no. 2, pp. 95-100.

56 S. Alexandrowicz, Kartografia..., p. 206.

57 The differences are marking the crossing of the Narew river at the height of the village of Zajki and removing the road leading to the mouth of the Biebrza at the Narew river, and choosing one main road to Tykocin and Suchowola. 
disabling travel in summer, but where journeys may be made in winter. ${ }^{58}$ Thus, the survey of these roads resulted in negative findings, though it did allow the catchment area of the Netta river and its mouth at the Biebrza to be added to the map. In addition, it showed where the Biebrza could be crossed.

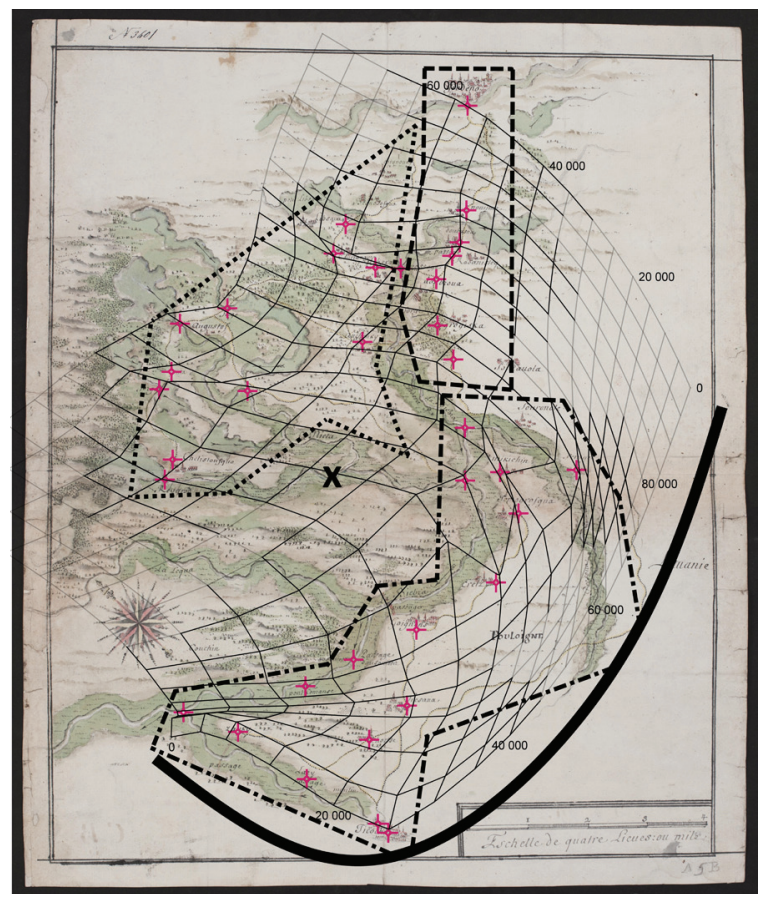

Figure 5. Distortion grid with the side of the distorted space marked. This presents the probable method of producing the Environs de Grodno et Ticochin map by Joseph-Gaspard Lambert de Guerin on the basis of the cartographic materials assembled during his field trips to survey the terrain. $\mathrm{X}$ the mouth of the Jerzgnia river at the Netta was recorded erroneously. Actually, this was the left tributary of the river Ełk

Source: the author's own study with the use of the MapAnalyst program on the basis of the Library of the Academy Sciences, St. Petersburg, Sobrane Rukopisnykh Kart, Osn. Op. 288.

58 S. Alexandrowicz, "Mappa szczegulna woiewództwa podlaskiego” Karola de Perthées z 1795 r., "Studia Podlaskie" 1990, vol. 1, p. 97; J. Wiśniewski, Dzieje osadnictwa..., p. 23. 
What was the cause of Lambert's mistakes? First of all, as I have proved on the basis of the analyses of toponyms, the cartographer did not use any printed maps. This thesis is based on two facts. First, the analysis of toponyms used by Lambert shows they are unique, not similar to any other cartographic sources. If Lambert had drawn based on existing maps, he would have used the names of settlements included there, instead of using the highly distorted, artificial names that he made up himself. Second, as a cartographer serving the Russian authorities he did not employ the names of settlements recorded on maps printed before $1706 .{ }^{59}$ Although previous cartographic output had been wholly imperfect as regards the tributaries of the Biebrza river, making use of them would have allowed fundamental mistakes to be avoided such as erroneously marking the Narew river and the lower course of the Biebrza. At that time, the Swedes were successfully using maps printed for the needs of military operations in the Commonwealth. ${ }^{60}$

Furthermore, unlike on the map by Maksim Tsyzyrev of 1701 (Fig. 3), the area was only surveyed along the roads. These routes led from Grodno (in two cases) and from Tykocin. The use of "guesstimation" (an approximation of distance ${ }^{61}$ ) in such difficult territory as the boggy catchment area of the Biebrza river was possible when simultaneously using a land and water survey. However, Russian cartographic services are not at fault here. The maps were produced in winter and early spring, so it was practically impossible to implement this technique. The map by Tsyzyrev proves that river surveys were known and successfully applied within Peter I's army.

The third problem was that at least one and possibly two roads were reconnoitred without the use of a compass. The lake area on the Rajgród-Augustów-Lipsk route was the best reproduced, as is also confirmed by the distortion grid. Perhaps the rivers were the point of reference. It must

59 K. Łopatecki, Two maps..., pp. 494-499.

60 Riksarkivet, Utan känd proveniens, no. 639, bl. 1. (kartavd., m. form.). The printed map presented the route marches of Swedish troops for the years 1702-1703.

${ }^{61}$ F. J. Kiński, Elementarz stuzby woyskowey, trans. A. F. B[rühl], Warszawa 1787, pp. 231-233. 
be stressed that the direction of the water courses was marked with arrows on both maps, constituting an important recognition element.

The fourth issue is the insufficient use of information from local residents, but also from the soldiers located between the Wizna lands and the larger part of the Bielsk lands. ${ }^{62}$ Additional information of this kind was sometimes (though not often) included. For example, the road leading from Augustów westward was probably surveyed only up to the settlement of Solistówka (Chelistousque), and the route was then supplemented with the nearby town of Rajgród, whose name was written in pencil. The addition was not accurate, however, as the name was erroneously recorded on the right of the Jerzgnia river. The key problem was probably the poor language skills of the French engineer-general.

As a result, the mean error in the location of stable points equals a striking $10.95 \mathrm{~km}$. The shapes of lakes and the course of the rivers recorded are especially unreliable. This particularly refers to the areas located south of the Augustów-Rajgród road up to the river Biebrza. The most serious, however, was the mix-up in the geographical directions. This is the most visible when we take the old map as a reference point for the modern map. ${ }^{63}$ This transformation I have superimposed on a contemporary map (Fig. 6).

Another problem that can be raised is the lack of precisely marked settlement symbols, which resemble itinerarium pictum more than map symbols. All the recorded towns were located on the marked roads, ${ }^{64}$ while the symbols found on the map may be misleading. The symbols of settlements were very often placed far away from the roads. ${ }^{65}$ This applies, for example,

62 Information on the use of "kaluzas", i.e., people well versed in local roads and byways, can be found in: M. Skrodzki to [S. A. Szczuka], Szczuczyn 28.03.1707, AGAD, Potocki Public Archive, sygn. 163a, vol. 38, p. 329.

63 A similar solution is proposed in: K. Nieścioruk, op. cit., p. 279.

64 More information on the road network for the area presented on the map can be found in: Opisy parafii dekanatu knyszyńskiego z roku 1784, red. W. Wernerowa, "Studia Podlaskie" 1990, vol. 1, pp. 99-217; Rękopiśmienne opisy parafii litewskich z 1784 roku. Dekanat grodzieński, ed. W. Wernerowa, Warszawa 1994.

65 Settlements were represented using conventional groups of buildings, usually showing the church and the regular housing. The towns also included many other buildings 
to Suchowola (Sourauola), which actually was located on the route from Grodzisk to Mikiciny and Skindzierz.
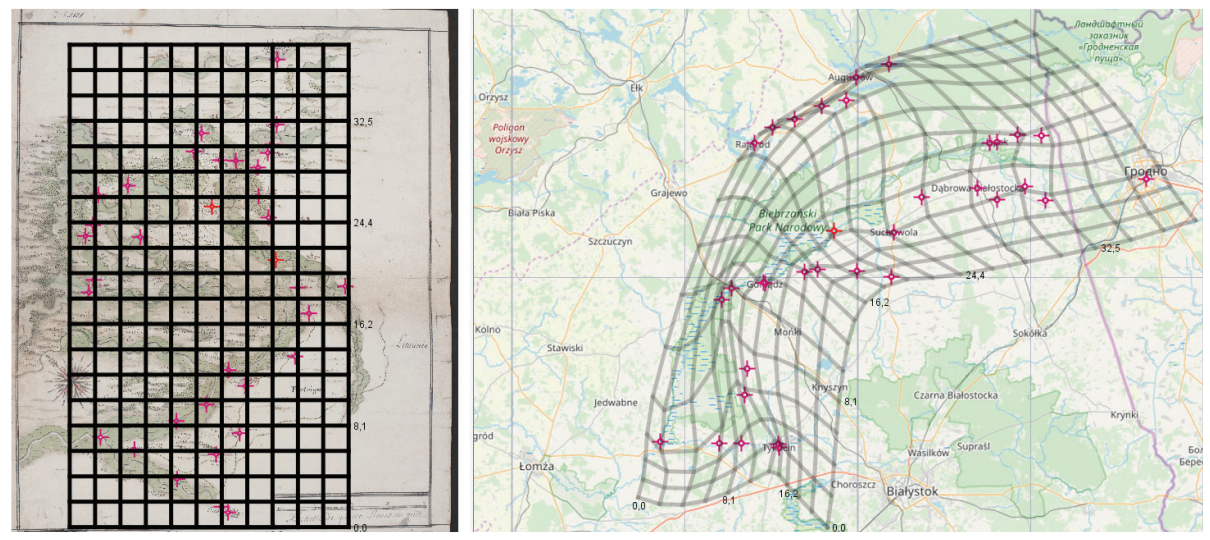

Figure 6. Comparison of the area recorded on the Environs de Grodno et Ticochin (Library of the Academy Sciences, St. Petersburg, Sobrane Rukopisnykh Kart, Osn. Op. 288) with a contemporary map

Source: the author's own study with the use of the MapAnalyst program.

It must be added that one road was also left unfinished on the Carte. The lines along the northern bank of the Brzozówka river were only drawn in pencil (Fig. 7b). This may indicate that the cartographic work was not completed, possibly because Lambert had left his job and had fled to Danzig, and subsequently to Western Europe. In particular, part of the road and towns connecting Grodno with Tykocin via Sidra-Janów-Korycin-Jasionówka-Knyszyn were not recorded (a probable reconstruction of the routes only sketched - Fig. 9).

As a result of a mistake resulting from juxtaposing three maps into one, Suchowola was likely recorded twice on the map (Fig. $7 b$ - Sourauola

(the town hall or churches of other denominations). The highest numbers of such objects are in Grodno (6 - including one characteristic Orthodox church), Tykocin (3), and Goniądz (2). The characteristic feature of the Environs is that it was not completed. Some settlements do not have building symbols. This refers to Rajgród, Netta, and Osowiec; the symbol of the mill is lacking as well. This also shows how towns were noted freely, without any care for precision. 
and Souronole). This misunderstanding resulted from the fact that the settlement led to Goniądz (via Mikicin) and yet allowed one to choose another way to Tykocin via Skindzierz, Korycin, Jasionówka and Knyszyn (Fig. 7a). For Lambert, Polish toponyms were completely foreign. He distorted the names terribly, attempting to use French-sounding versions of the names. Spelling the name of one settlement in two different ways on two road maps led to its cloning. This error was included in the Carte and was not to be corrected in the Environs.

a

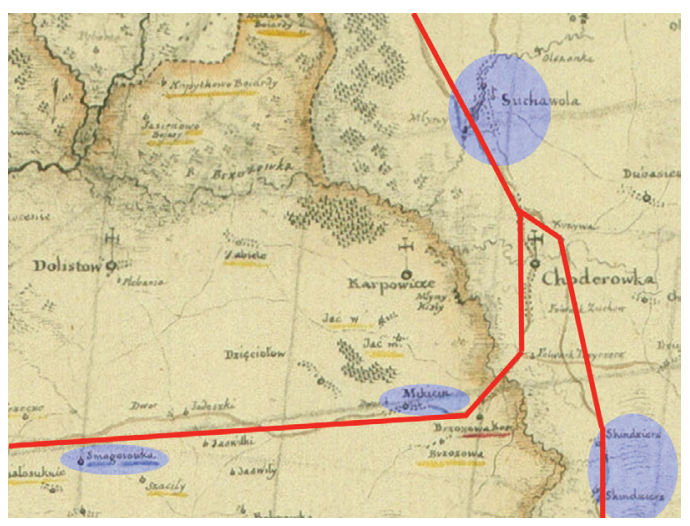

b

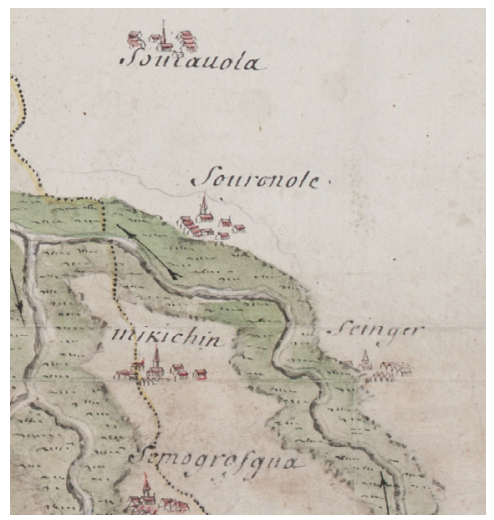

Figure 7. The road connecting Dąbrowa Białostocka with Suchowola and the fork of the roads leading to Goniądz (through Mikiciny and Smogorówka) and to Korycin and Knyszyn through Skindzierz on the Mappa szczegulna woiewództwa podlaskiego by Karol Perthees (7a) and on the Environs de Grodno et Ticochin by Joseph-Gaspard Lambert de Guerin (7b)

Despite all of these errors, military cartographic services were very useful for the Russian army. First, it was found that a column of soldiers were unable to move along the left bank of the river Biebrza. Second, the operation of crossing the Narew was planned in detail and potential crossings for the Biebrza were determined. The former was important given the planned retreat of the Russian troops. The latter was related to a possible attack by the Swedish army (the Russians mostly feared the light cavalry). ${ }^{66} \mathrm{I}$ have

${ }^{66}$ M. Skrodzki to S. A. Szczuka, Szczuczyn 12.03.1706, AGAD, Potocki Public Archive, sygn. 163a, vol. 38, p. 210; the former to the latter, Szczuczyn 17.03.1706, ibidem, p. 213. 
already mentioned the bridge made by the Deputy Chancellor Szczuka and the Russian troops. Other crossings were also marked. In the lower course of the Biebrza river, these were at Osowiec and at Goniądz. Both were in operation for the years 1705-1706. The crossing at Goniądz was organised by the Polish-Lithuanian troops allied with Peter I after confiscating a ferry and boats at Osowieed ${ }^{67} \mathrm{~A}$ crossing at Lipsk is also confirmed on Swedish operational maps of 1708 (Fig. 8). The reduced number of crossings on the Biebrza river presented on the Environs when compared to the Carte may suggest the advancing early spring thaw, which limited travel.

To assess both maps, we must conclude that they are important cartographic relics but that they are not free of significant errors. They reflect a lower level of detail than contemporary Swedish maps produced in the Commonwealth. ${ }^{68}$ First of all, Scandinavian engineers reproduced the river network more precisely, taking into consideration even small tributaries; they also included details of roads with precisely located towns and villages (more of them were represented on the maps, not only those directly located on marching routes) (Fig. 8). They reflected the local names of towns and rivers far better, while the different types of land (bogs, woods, lakes) were marked with comparable accuracy. Even in the mid-1 $7^{\text {th }}$ c., Swedish cartographers did not have any serious problems with juxtaposing several medium-scale maps and itineraries within a single map. ${ }^{69}$ Unfortunately, the Environs is an unsuccessful attempt to transform itineraria picta and field sketches into a medium-scale map.

67 M. Skrodzki to [A. S. Szczuka], [possibly Szczuczyn 4.05.1705], Potocki Public Archive, sygn. 163a, vol. 38, p. 357.

68 For comparison purposes, I have used: Riksarkivet, Wijksamlingen, Kartor och ritningar, 0039 : 00001-00002 (route from Warsaw to Grodno and a detailed fragment of the crossing of the Biebrza river near Różanystok - both conducted in 1702) and Krigsarkivet, Sveriges Krig, 11 : 160 (map presenting the route from Nieszawa through Grodno to Raduń of 1708).

69 K. Łopatecki, Prace kartograficzne wykonane na ziemiach Rzeczypospolitej przez szwedzkich inżynierów wojskowych $w$ XVII stuleciu, "Studia i Materiały do Historii Wojskowości” 2009, vol. 46, pp. 72-74. 


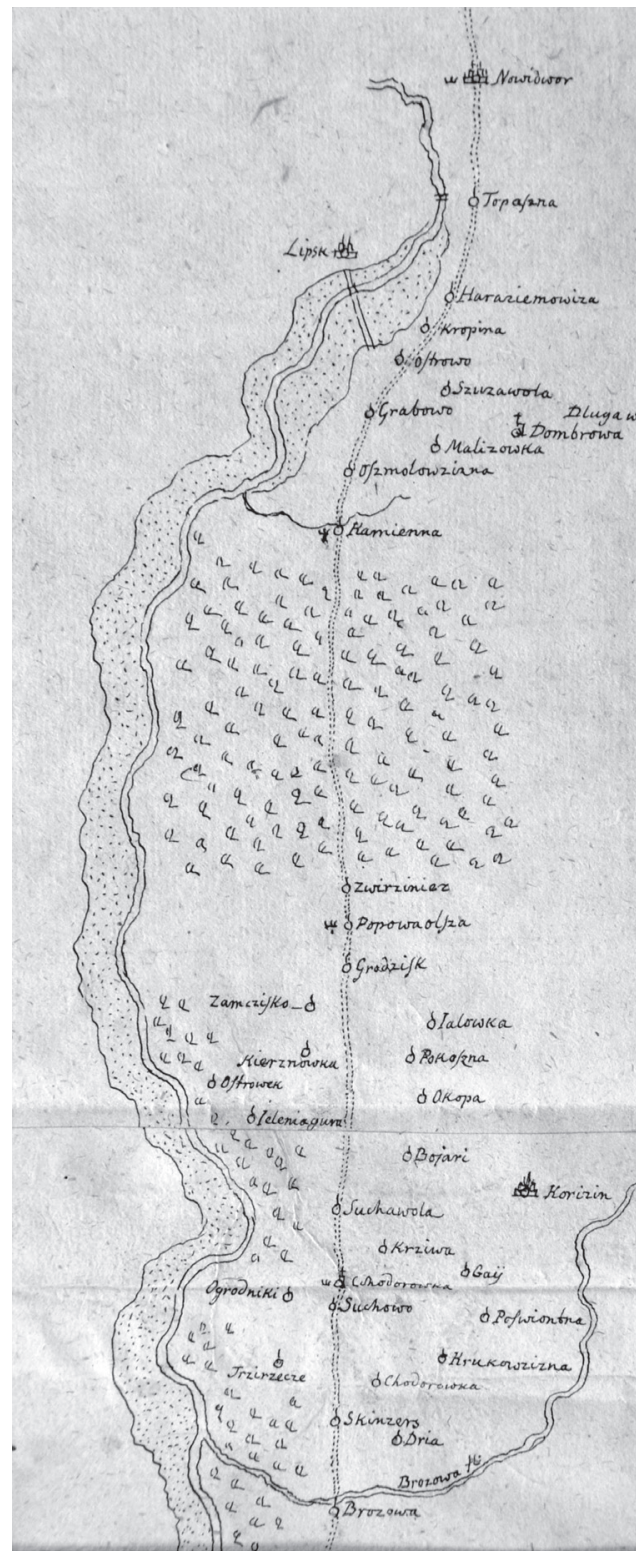

Figure 8. March of the Swedish army from Brzozowo to Nowy Dwór in 1708 (Nieschawa-Johannisburg-Grodno-Sabloze)

Source: Krigsarkivet, Sveriges Krig, $5: 47$ (part of the map). 


\section{Conclusion}

The two maps entitled Carte d'une partie de la Lithuanie et de la Pologne and Environs de Grodno et Ticochin kept at the Library of the Academy of Sciences in St. Petersburg were produced by the same author: an engineer-general serving in the army of Peter I, Joseph-Gaspard Lambert de Guerin (in Russian: Žozef Gaspar Lamber de Geren [Жозеф Гаспар Аамбер ме Герен]). He served in the Russian army between 1701-1706. Both analysed maps were created in the first three months of 1706 for the needs of the Grodno Campaign. Lambert's works were used when preparing the withdrawal of Peter I's army from Grodno to the Ukraine. The Russians and their allies left Grodno (22.03/2.04) and reached the safety of the Ukraine via Tykocin (29.03/9.04) and Brest Litovsk (4/15.04). The calculated average daily marching speed from Grodno to Kiev was 18.9 km, but the fastest section between Tykocin and Bielsk Podlaski was covered at an average daily speed of $34.4 \mathrm{~km}$. The success of this operation would have been impossible without precise reconnaissance, especially in the first, most dangerous stage of reaching the river Narew and crossing it.

Both maps show communication routes between Tykocin and Grodno, and they also include the possible crossings over the Biebrza and Narew rivers. Towns were only marked along the roads, with other settlements being ignored completely. Symbols were very often placed next to the marked roads, not on them, which can be misleading (Fig. $7 \mathrm{~b}$ ). The role of military cartographers was shown using the example of the two maps. In operational activities, they must have collaborated with the quartermaster in order to locate the troops stationed in particular settlements and towns, for which purpose specially-made maps were produced. The other task was to provide a cartographic representation of the area for any future march, to determine the possible routes and to show the settlements along the roads themselves. It was necessary to mark any possible river and marshland crossings and to record all obstacles. The maps herein presented belong to the latter category. The characteristic feature of both cartographic works is the presentation of river courses, which provided considerable orientational help in marshy and flat terrain. 
The conducted analysis proves that both maps were produced as a result of reconnoitring the area along the marked roads, and that this was slightly supplemented with oral information gained from local residents or soldiers. Three sketches were made on trips from Tykocin (in one case) and Grodno (in two cases). They resulted in the production of cartographic sketches, such as the Carte d'une partie de la Lithuanie et de la Pologne (Fig. 4). This map includes a key error in the orientation of the course of the Narew river and the lower course of the river Biebrza (Fig. 6). Environs de Grodno et Ticochin compiled by Lambert was a combination of three sources into one (Fig. 5). Unfortunately, in cartographic terms, it was a failure for several reasons:

- existing printed maps were not used;

- the reconnaissance along the rivers and lakes was not complete, just as with the map of the surroundings of the Daugava river by Maksim Tsyzyrev of 1701;

- during at least one trip, no compass was used, which led to mistakes in geographical directions;

- the material was not sufficiently supplemented with local residents' knowledge.

As a result of juxtaposing three sketches, significant distortions occurred, ones visible on the distortion grid (Fig. 5). In the south-western part of the map, the town of Suchowola was probably recorded twice, through the use of similar though not identical names. There is some evidence to suggest that Lambert did not complete the Environs de Grodno et Ticochin. This is suggested by the unfinished road (only marked in pencil) from Suchowola to Skindzierz, as well as the lack of the subsequent part of the road from Grodno to Tykocin via Sidra-Janów-Korycin and Knyszyn. Below I present a schematic map with the inclusion of these two roads. 


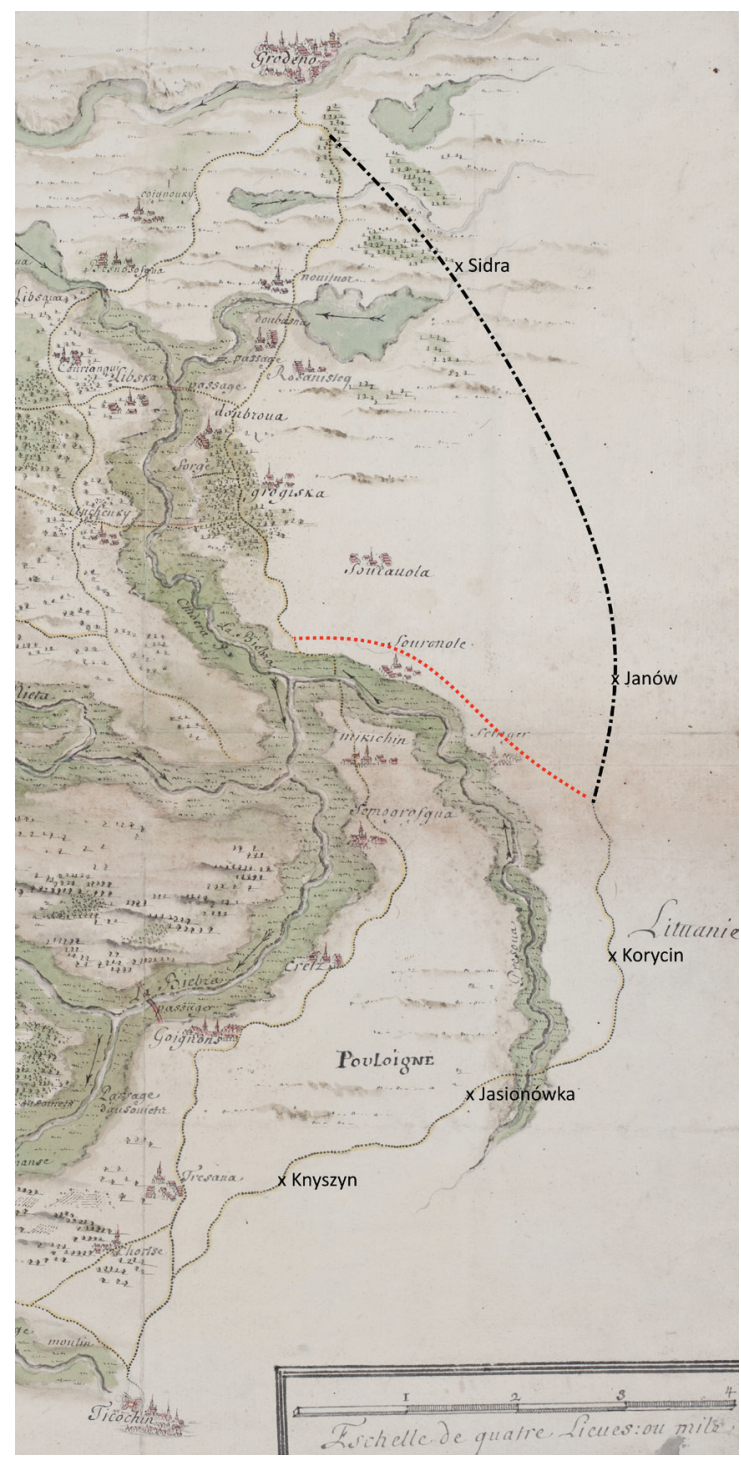

Figure 9. Probable planned final version of the Environs de Grodno et Ticochin (Library of the Academy of Sciences, St. Petersburg, Sobrane Rukopisnykh Kart, Osn. Op. 286) map including the route from Suchowola to Skindzierz $(\bullet \bullet)$ and the unfinished Eastern route from Grodno to Tykocin $(\bullet-\bullet-)$ and the schematically marked $(\mathrm{x})$ main towns and villages

Source: the author's own study. 